\title{
Correction to: A comparative genomic analysis of putative pathogenicity genes in the host-specific sibling species Colletotrichum graminicola and Colletotrichum sublineola
}

\author{
E. A. S. Buiate ${ }^{1,2+}$, K. V. Xavier ${ }^{1 \dagger}$, N. Moore ${ }^{3}$, M. F. Torres ${ }^{1,4}$, M. L. Farman' ${ }^{1}$ C. L. Schardl ${ }^{1}$ and L. J. Vaillancourt ${ }^{1 *}$
}

\section{Correction}

The authors wish to make it known that they mistakenly used some unpublished data from the Joint Genome Institute (JGI) database in some parts of this article in a way that violates the JGI usage agreement. They are therefore issuing a correction to their article [1] in which Fig. 14 and all text in the article that refers to results involving JGI data are excluded. Specifically, the sections to be disregarded are comparisons to the JGI sequences described in the section titled "Characteristics of the $C$. graminicola and C. sublineola NCPs": comparisons with S3.001 from the section titled "SSP and SSM diversity among isolates": and the summarized numbers of unique SSPs and SSMs in the abstract. The revised sentence in the abstract should read "Only 98 SSP genes appeared to be specific to C. graminicola, and 103 to C. sublineola". It is important to note that these revisions do not change the conclusions of the paper in any meaningful way. The authors apologize to Dr. Crouch and the other principal investigators of the relevant JGI Community Sequencing Project (https://genome.jgi.doe.gov/portal/Gensignviron ment/Gensignvironment.info.html) for this error.
Author details

'Department of Plant Pathology, University of Kentucky, 201F Plant Science Building, 1405 Veterans Drive, Lexington, KY 40546-0312, USA. ²Present

Address: Monsanto Company Brazil, Uberlândia, Minas Gerais, Brazil. ${ }^{3}$ Department of Computer Science, University of Kentucky, Davis Marksbury Building, 328 Rose Street, Lexington, KY 40504-0633, USA. ${ }^{4}$ Present Address: Functional Genomics Laboratory, Weill Cornell Medicine, Doha, Qatar.

Received: 11 September 2018 Accepted: 11 September 2018 Published online: 19 September 2018

\section{Reference}

1. Buiate EA, et al. A comparative genomic analysis of putative pathogenicity genes in the host-specific sibling species Colletotrichum graminicola and Colletotrichum sublineola. BMC Genomics. 2017;18:67. https://doi.org/10. 1186/s12864-016-3457-9.

* Correspondence: vaillan@uky.edu

${ }^{\dagger}$ E. A. S. Buiate and K. V. Xavier contributed equally to this work.

1 Department of Plant Pathology, University of Kentucky, 201F Plant Science

Building, 1405 Veterans Drive, Lexington, KY 40546-0312, USA

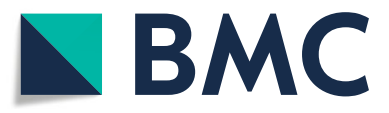

(c) The Author(s). 2018 Open Access This article is distributed under the terms of the Creative Commons Attribution 4.0 International License (http.//creativecommons.org/licenses/by/4.0/), which permits unrestricted use, distribution, and reproduction in any medium, provided you give appropriate credit to the original author(s) and the source, provide a link to the Creative Commons license, and indicate if changes were made. The Creative Commons Public Domain Dedication waiver (http://creativecommons.org/publicdomain/zero/1.0/) applies to the data made available in this article, unless otherwise stated. 